\title{
Gambaran Kesadaran dan Intensi Remaja Kurus Tentang Latihan Fisik
}

\author{
Farah Diba $^{1^{*}}$, Zahtamal ${ }^{2}$, Imelda Pardede ${ }^{3}$
}

\begin{abstract}
Underweight is a public health problem and the incidence rate is still increasing worldwide, including in Indonesia. This condition is more common in adolescents due to inadequate food intake and lack of nutritional knowledge. The other factor that determines nutritional status is physical exercise. The purpose of this study was to describe the awarenesss and intentions of underweight adolescents about physical exercise. This research was a quantitative descriptive study. It was conducted at SMA Negeri 5 and 3 in Pekanbaru. Ninety two underweight subjects were obtained by purposive sampling technique. Data collected using questionnaire and then analyzed by univariate analysis. The results of this study found that $63 \%$ underweight adolescent were female and they were experiencing mild to severe underweight. Most subjects have moderate awareness (77.2\%) and good intention (64.13\%) about physical exercise. It can be concluded that underweight adolescents have moderate awareness and good intention about physical exercise, despite they are being underweight.
\end{abstract}

Keyword : intention, awareness, physical exercise, adolescents, underweight.

Menurut WHO seseorang dikatakan status gizi kurang jika indeks massa tubuh (IMT) $<18,5 \mathrm{~kg} / \mathrm{m}^{2}{ }^{1}$ Berdasarkan National Health and Nutrition Examination Survey (NHANES) di Amerika Serikat tahun 2003-2006 menunjukkan peningkatan kasus remaja kurus pada remaja usia 12-19 tahun dari 3,8\% menjadi 6,5\% pada tahun 2007-2010. ${ }^{2}$ Data dari Riset Kesehatan Dasar (Riskesdas) di Indonesia tahun 2013 sebanyak 9,4\% remaja usia 16-18 tahun mengalami status gizi kurang, hal ini menunjukkan peningkatan kasus yang sebelumnya hanya 8,9\% pada tahun 2010. Jumlah remaja kurus di Provinsi Riau tahun 2010-2013 mengalami sedikit peningkatan dari 7,8\% menjadi 7,9\% sedangkan di Pekanbaru sebanyak 5,7\%.3,4

Latihan fisik merupakan kegiatan yang dilakukan seseorang untuk meningkatkan dan

\footnotetext{
* Correspondent author: email: farah.tanjung3938 @student.unri.ac.id

1 Mahasiswa Fakultas Kedokteran Universitas Riau, Pekanbaru, Riau, Indonesia

2 KJFD Ilmu Kesehatan Masyarakat Fakultas Kedokteran Universitas Riau, Pekanbaru, Riau, Indonesia

3 KJFD Ilmu Gizi Fakultas kedokteran Universitas Riau, Pekanbaru, Riau, Indonesia
}

memelihara kebugaran tubuh, serta dianjurkan pada setiap individu agar terhindar dari berbagai macam penyakit. ${ }^{5}$ Pada saat melakukan latihan fisik dengan intensitas yang tinggi membutuhkan banyak energi tetapi asupan makanan kurang daripada energi yang keluar, maka akan terjadi status gizi kurang.,7 Kesadaran adalah kemampuan seseorang menyadari pengalaman subjektifnya, kemampuan seseorang mempersepsi variasi-variasi keadaan mental dan perilaku. ${ }^{8}$ Intensi adalah komponen dalam diri individu yang mengacu pada keinginan untuk melakukan tingkah laku tertentu. ${ }^{9}$

Remaja menurut World Health Organization (WHO) adalah penduduk yang berumur antara 10 19 tahun. ${ }^{10}$ Remaja mengalami pertumbuhan fisik yang cepat (growth spurt). Pertumbuhan fisik yang terjadi pada remaja seperti meningkatnya tinggi badan dan berat badan, pertumbuhan skeletal disertai peningkatan massa tulang, perubahan proporsi tubuh dan timbulnya ciri-ciri sekunder. ${ }^{11}$

Remaja di pusat kota cenderung ingin memiliki bentuk tubuh yang ideal karena pengaruh teman sebaya dan sosial media, sehingga melakukan berbagai cara untuk mencapai hal tersebut. Kebanyakan remaja melakukan metode diet yang 
tidak sesuai dengan pengetahuan gizi yang cukup dan intensitas pada latihan fisik yang tinggi sehingga terjadi ketidakseimbangan antara kebutuhan dengan asupan makan. ${ }^{12}$ Remaja di pinggiran kota atau di pedesaan cenderung dipengaruhi faktor ekonomi dimana pendapatan keluarga rendah sehingga tidak dapat memenuhi kebutuhan pangan yang baik. Hal ini dapat menimbulkan status gizi kurang. ${ }^{13}$

Berdasarkan informasi dan survei peneliti, SMA Negeri 5 di Kota Pekanbaru terletak di pusat Kota Pekanbaru dan sebagian siswanya memiliki kegiatan belajar di sekolah, ekstrakurikuler, maupun kegiatan di luar sekolah yang cukup padat. Sedangkan di SMA 3 Negeri di Kota Pekanbaru merupakan sekolah yang terletak di daerah pinggiran kota dan sebagian siswanya berasal dari perekonomian yang menengah ke bawah. Oleh karena hal tersebut, peneliti ingin melakukan penelitian di SMA Negeri 5 dan SMA Negeri 3 Pekanbaru. Terkait dengan latar belakang di atas dan belum terdapatnya data penelitian yang menunjukkan adanya gambaran kesadaran dan intensi remaja kurus tentang latihan fisik di Kota Pekanbaru, maka peneliti tertarik untuk melakukan penelitian tersebut.

\section{METODE}

Jenis penelitian ini adalah deskriptif kuantitatif dengan desain survei. Penelitian ini dilakukan di SMA Negeri 5 dan SMA Negeri 3 Pekanbaru pada bulan September 2018-Juli 2019. Penelitian ini dilakukan setelah dinyatakan lulus uji etik oleh Unit Etika Penelitian Kedokteran dan Kesehatan Fakultas Kedokteran Universitas Riau dan dinyatakan lolos kaji etik dengan dengan nomor: 196/UN.19.5.1.1.8/ UEPKK/2018/rev-1. Populasi dalam penelitian ini adalah seluruh siswa yang mengalami status gizi kurang yang ada di SMA Negeri 5 Pekanbaru dan
SMA Negeri 3 Pekanbaru. Besar sampel minimal menggunakan rumus Lemeshow dan ditambah $10 \%$ untuk mengantisipasi drop out, sehingga diperoleh sampel sebanyak 92 subjek dengan teknik purposive sampling yang memenuhi kriteria inklusi dan eksklusi. Adapun kriteria inklusi yaitu subjek peneliti yang dikategorikan gizi kurang berdasarkan IMT, responden bersedia menjadi subjek penelitian, serta mengisi identitas dengan lengkap dan mengisi kuesioner. Sedangkan kriteria eksklusinya yaitu subjek penelitian yang sedang menderita penyakit infeksi, penyakit metabolik dan gangguan perilaku makan. Untuk kriteria drop out apabila subjek penelitian tidak mengikuti prosedur penelitian hingga selesai dan mengisi kuesioner penelitian dengan tidak lengkap. Pengambilan data dalam penelitian ini menggunakan kuesioner, terdiri dari 8 pertanyaan tentang kesadaran dan 8 pertanyaan tentang intensi remaja kurus terhadap latihan fisik. Kuesioner diadopsi dari penelitian Zahtamal dkk. ${ }^{14}$ Kuesioner telah diuji validitas menggunakan batasan koefisien korelasi $\geq 0,2$ dan reliabilitas dengan nilai Cronbach Alpha $\geq 0,6$ melalui bantuan komputerisasi. ${ }^{15}$ Penelitian ini menggunakan analisis univariat. Analisis ini mendeskripsikan karakteristik variabel yang diteliti, sehingga akan terlihat distribusi dan persentasi dari data kesadaran dan intensi tentang latihan fisik. Data yang diperoleh akan ditampilkan dalam bentuk tabel dengan menggunakan persentase dan pie chart.

\section{HASIL}

Penelitian ini dilakukan dengan total subjek sebanyak 92 orang. Karakteristik subjek penelitian digambarkan pada Tabel 1 berikut: 
Tabel 1. Karakteristik subjek penelitian

\begin{tabular}{|c|c|c|}
\hline Variabel & Jumlah Sampel & Persentase (\%) \\
\hline \multicolumn{3}{|l|}{$\begin{array}{c}\text { Seluruh subjek }(n=92) \\
\text { Jenis Kelamin }\end{array}$} \\
\hline - Laki-laki & 34 & 37,0 \\
\hline 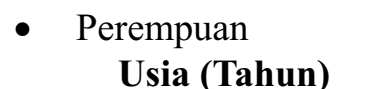 & 58 & 63,0 \\
\hline - 15 & 7 & 7,6 \\
\hline - 16 & 53 & 57,6 \\
\hline - 17 & 32 & 34,8 \\
\hline \multicolumn{3}{|l|}{ IMT } \\
\hline \multicolumn{3}{|c|}{ Subjek di Pusat Kota (SMAN 5 Pekanbaru, $n=46)$} \\
\hline Jenis Kelamin & & \\
\hline - Laki-laki & 14 & 30,4 \\
\hline 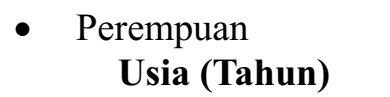 & 32 & 69,6 \\
\hline - 15 & 4 & 8,7 \\
\hline - 16 & 30 & 65,2 \\
\hline - 17 & 12 & 26,1 \\
\hline \multicolumn{2}{|l|}{ IMT } & \\
\hline \multicolumn{3}{|c|}{ Subjek di Pinggiran Kota (SMAN 3 Pekanbaru, $n=46)$} \\
\hline - Laki-laki & 20 & 43,5 \\
\hline 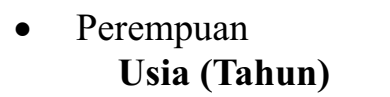 & 26 & 56,5 \\
\hline - 15 & 3 & 6,5 \\
\hline - 16 & 23 & 50,0 \\
\hline - 17 & 20 & 43,5 \\
\hline $\begin{array}{cc} & \text { IMT } \\
\text { - } \quad \text { Median (min-mak) } \\
\end{array}$ & $17,71(15,36-18,46)$ & \\
\hline
\end{tabular}

Tabel 1. menunjukkan bahwa sebagian besar subjek berjenis kelamin perempuan yaitu sebanyak 58 orang $(63,0 \%)$. Usia subjek yang terbanyak adalah 16 tahun, berjumlah 53 orang (57,6\%). Nilai median IMT yaitu 17,80 (13,86-18,48 kg/m²). Sebagian besar subjek yang mewakili daerah pusat Kota Pekanbaru berjenis kelamin perempuan, yaitu sebanyak 32 orang (69,6\%) dengan usia terbanyak yaitu 16 tahun, sejumlah 30 orang (65,2\%). Untuk sebaran status nutrisi didapatkan nilai median IMT yaitu 17,83 (13,86-18,48 kg/m²). Begitu pula di daerah pinggiran Kota Pekanbaru didapatkan sebagian besar subjek berjenis kelamin perempuan, yaitu sebanyak 26 orang (56,5\%) dengan usia terbanyak adalah 16 tahun, sejumlah 23 orang (50,0\%). Untuk sebaran status nutrisi didapatkan nilai median IMT yaitu 17,71 (15,36-18,46).

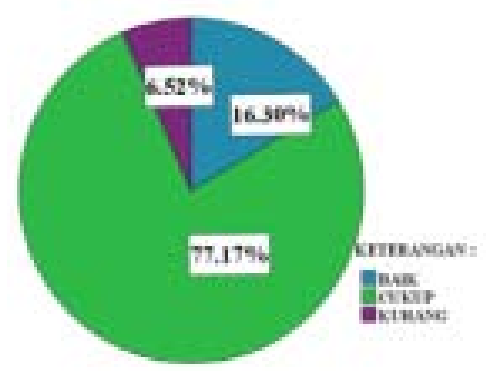

Gambar1 Kesadaran remaja kurus tentang latihan fisik pada keseluruhan subjek (SMA Negeri 5 dan SMA Negeri 3 Kota Pekanbaru) 
Pada gambar 1 dapat dilihat bahwa sebagian besar kesadaran remaja kurus tentang latihan fisik dalam kategori cukup yaitu sebanyak 71 orang $(77,2 \%)$. Kategori yang paling sedikit yaitu kategori kurang sebanyak 6 orang (6,5\%).

Apabila diperhatikan pada gambar 2 sebaran subjek di SMA 5 dan SMA 3 tampak bahwa karakteristik subjek di kedua tempat hampir sama.

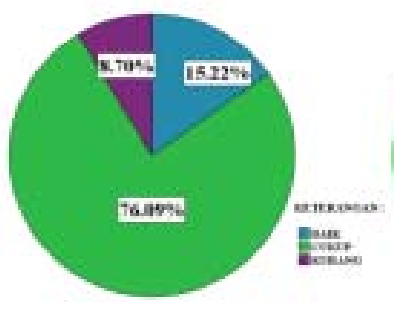

A

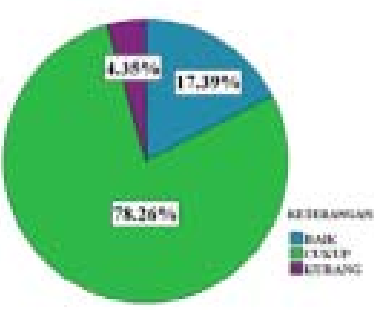

B
Gambar 2. A. Kesadaran remaja kurus tentang latihan fisik pada SMA Negeri 5 Pekanbaru

B. Kesadaran remaja kurus tentang latihan fisik pada SMA Negeri 3 Pekanbaru

Berdasarkan Gambar 2 dapat dilihat bahwa sebagian besar remaja kurus di SMA Negeri 5 Pekanbaru memiliki kesadaran tentang latihan fisik dalam kategori cukup, yaitu 35 orang (76,09 \%). Hanya 15,22\% (7 orang) yang memiliki kesadaran baik. Hal serupa didapatkan di SMA 3, sebagian besar subjek remaja kurus memiliki kesadaran tentang latihan fisik 78,3\% (36 orang) dan hanya 17,39\% (8 orang) yang memiliki kesadaran baik.

Berdasarkan kuesioner tentang aspek kesadaran, pernyataan favorable yang paling banyak dijawab "Ya" oleh seluruh subjek di kedua sekolah adalah pernyataan nomor 2 "(saya telah memahami bahwa latihan fisik dapat membantu saya tidak lagi mengalami status gizi kurang (berat badan kurang.))" yang dijawab oleh 74 orang (80,4\%), yaitu masing-masing 36 orang (78,3\%) di SMA Negeri 5 Pekanbaru dan 38 orang (82,6\%) di SMA Negeri 3 Pekanbaru. Jawaban "Ya" kedua terbanyak oleh seluruh subjek di kedua sekolah adalah pernyataan unfavorable nomor 8 yaitu "(saya tidak yakin dengan mengatur latihan fisik tubuh saya akan kembali sehat.)", yaitu masing-masing sekolah 65,2\% (30 orang) di SMA Negeri 5 Pekanbaru dan 58,7\% (27 orang) di SMA Negeri 3 Pekanbaru.
Jawaban "Tidak" yang paling banyak dijawab oleh seluruh subjek di kedua sekolah adalah pernyataan favorable nomor 7 yaitu "(saya memahami perlunya latihan fisik secara teratur karena dapat meningkatkan berat badan.)” yang dijawab oleh 73 orang (79,3\%), yaitu masing-masing 38 orang $(54,3 \%)$ di SMA Negeri 5 Pekanbaru dan 35 orang $(76,1 \%)$ di SMA Negeri 3 Pekanbaru.

Jawaban "Tidak" kedua tebanyak oleh seluruh subjek di pusat kota Pekanbaru (SMA Negeri 5 Pekanbaru) adalah pernyataan unfavorable nomor 1 yaitu "(saya belum pernah mendengar tentang cara melakukan latihan fisik.)" dijawab oleh 56,5\% (24 orang).

Pernyataan favorable yang paling sedikit dijawab "Ya" oleh seluruh subjek adalah pernyataan nomor 7 yaitu "(saya memahami perlunya latihan fisik secara teratur karena dapat meningkatkan berat badan.)" dijawab oleh 19 orang (20,7\%) yaitu masing-masing 8 orang $(17,4 \%)$ di SMA Negeri 5 Pekanbaru dan 11 orang (23,9\%) di SMA Negeri 3 Pekanbaru.

Jawaban "Ya" yang paling sedikit kedua oleh seluruh subjek di pinggiran kota Pekanbaru (SMA Negeri 5 Pekanbaru) adalah pernyataan unfavorable nomor 5 yaitu "(saya tidak memahami hubungan antara latihan fisik dengan status gizi kurang (berat badan kurang.))" dijawab oleh 41,3\% (19 orang).

Pernyataan favorable yang paling sedikit dijawab "Tidak" oleh seluruh subjek di kedua sekolah adalah pernyataan nomor 2 yaitu "(saya telah memahami bahwa latihan fisik dapat membantu saya tidak lagi mengalami status gizi kurang (berat badan kurang.))" yang dijawab oleh 18 orang (38,0\%), yaitu masing-masing sekolah 21,7\% (10 orang) di SMA Negeri 5 Pekanbaru dan 17,4\% (8 orang) di SMA Negeri 3 Pekanbaru.

Jawaban "Tidak" kedua yang paling sedikit oleh seluruh subjek di kedua sekolah adalah pernyataan unfavorable nomor 8 yaitu "(saya tidak yakin dengan mengatur latihan fisik tubuh saya akan kembali sehat.)" yaitu masing-masing 16 orang (34,8\%) di SMA Negeri 5 Pekanbaru dan 19 orang (41,3\%) di SMA Negeri 3 Pekanbaru. 
Berikut ini adalah gambaran intensi remaja kurus tentang latihan fisik pada keseluruhan subjek penelitian :

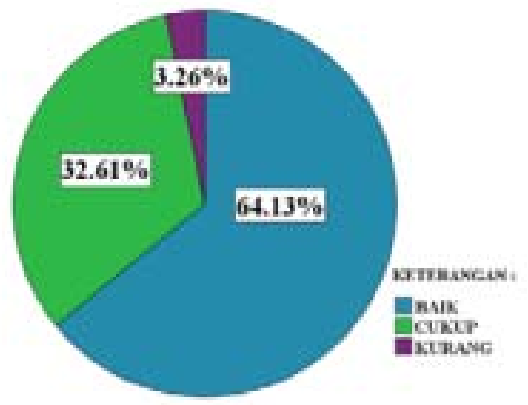

Gambar 3. Intensi remaja kurus tentang latihan fisik pada keseluruhan subjek (SMA Negeri 5 dan SMA Negeri 3 Kota Pekanbaru)

Pada gambar 3 dapat dilihat bahwa sebagian besar intensi remaja kurus tentang latihan fisik dalam kategori baik yaitu sebanyak 59 orang $(64,1 \%)$. Hanya 3,26\% (3 orang) yang termasuk kategori kurang.

Apabila diperhatikan pada gambar 4 sebaran subjek di SMA 5 dan SMA 3 tampak bahwa karakteristik subjek di kedua tempat hampir sama.

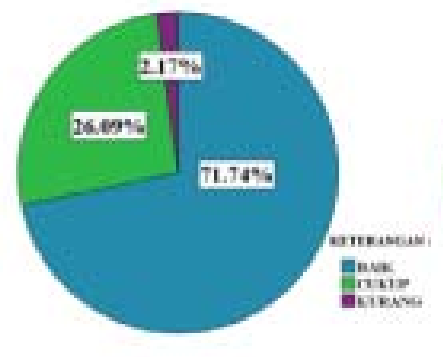

A

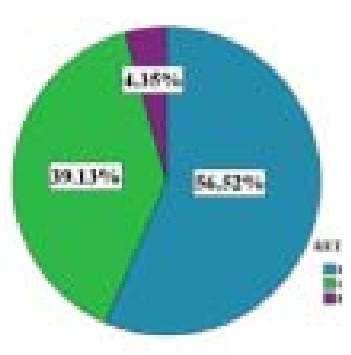

B
Gambar 4. A. Intensi remaja kurus tentang latihan fisik pada SMA Negeri 5 Pekanbaru

B. Intensi remaja kurus tentang latihan fisik pada SMA Negeri 3 Pekanbaru

Berdasarkan Gambar 4 dapat dilihat bahwa sebagian besar remaja kurus di SMA Negeri 5 Pekanbaru memiliki intensi tentang latihan fisik dalam kategori baik yaitu sebanyak 33 orang $(71,7 \%)$. Hanya 2,2\% (1 orang) yang termasuk kategori kurang.
Hal serupa didapatkan di SMA 3 Pekanbaru, sebagian besar subjek remaja kurus memiliki intensi tentang latihan fisik dalam kategori baik yaitu sebanyak 56,5\% (26 orang). Hanya 4,3\% (2 orang) yang memiliki kategori kurang.

Berdasarkan kuesioner tentang aspek intensi, pernyataan "Sangat Ingin” yang paling banyak dijawab oleh seluruh subjek di kedua sekolah adalah pernyataan nomor 1 yaitu "(saya sebagai penderita berat badan kurang "Sangat Ingin” meluangkangkan waktu untuk berolahrga yang tepat atau sesuai panduan.)" dijawab oleh 55 orang (59,8\%), yaitu masing-masing 30 orang (65,2\%) di SMA Negeri 5 Pekanbaru dan 25 orang (54,3\%) di SMA Negeri 3 Pekanbaru.

Pada pernyataan "Sangat Ingin” yang paling sedikit dijawab oleh seluruh subjek di kedua sekolah adalah pernyataan nomor 8, yaitu "(saya sebagai penderita berat badan kurang "Sangat Ingin” untuk pengelolaan latihan fisik yang saya lakukan tidak terhambat oleh alasan ketidaktersediaan fasilitas/ sarana olahraga.)" yang dijawab oleh 27 orang (29,3\%), yaitu masing-masing sekolah 45,7\% (21 orang) di SMA Negeri 5 Pekanbaru dan 13,0\% (6 orang) di SMA Negeri 3 Pekanbaru.

Pada pernyataan “Tidak Ingin” yang paling banyak dijawab oleh seluruh subjek di kedua sekolah adalah pernyataan nomor 8 yaitu "(saya sebagai penderita berat badan kurang "Tidak Ingin” untuk pengelolaan latihan fisik yang saya lakukan tidak terhambat oleh alasan ketidaktersediaan fasilitas atau sarana olahraga.)” dijawab oleh 12 orang (13,0\%), yaitu masing-masing 3 orang (6,5\%) di SMA Negeri 5 Pekanbaru dan 10 orang (54,3\%) di SMA Negeri 3 Pekanbaru.

Pada pernyataan “Tidak Ingin” yang paling banyak dijawab oleh seluruh subjek di pusat kota Pekanbaru (SMA Negeri 5 Pekanbaru) adalah pernyataan nomor 5 yaitu "(saya sebagai penderita berat badan kurang "Tidak Ingin” mengelola latihan fisik yang akan saya lakukan sesuai panduan.)" dijawab oleh 6,5\% (3 orang). 


\section{PEMBAHASAN}

\section{Karakteristik subjek}

Pada penelitian ini seluruh subjek (92 orang) mengalami gizi kurang. Sebagian besar subjek (58 orang; 63\%) berjenis kelamin perempuan, dan paling banyak (53 orang; $57,6 \%$ ) berusia 16 tahun. Hal ini sesuai dengan penelitian Deren yang menyatakan bahwa kondisi status gizi kurang paling banyak ditemukan pada perempuan dengan rentang usia 13-18 sebanyak 20,7\% dibandingkan dengan lakilaki sebanyak $10,8 \% .{ }^{16}$ Penelitian lain oleh Fryar menunjukkan bahwa status gizi kurang yang terjadi pada rentang usia 12-19 tahun sebanyak 6,5\%. ${ }^{2}$

Berdasarkan hasil penelitian ini (Tabel 1), didapatkan bahwa jumlah remaja kurus terbanyak adalah pada perempuan sebanyak 58 orang (63\%). Sedangkan laki-laki hanya 34 orang (37\%). Hal ini terjadi karena remaja menghadapi banyak permasalahan negatif mengenai gizi mereka karena remaja termasuk kelompok yang rentan mengalami permasalahan gizi, terutama remaja putri. ${ }^{17}$ Pada penelitian ini (Tabel 1), untuk semua status nutrisi subjek yang mengalami gizi kurang didapatkan rentang IMT $13,86-18,48 \mathrm{~kg} / \mathrm{m}^{2}$ terdiri dari tingkat ringan $\left(17,0-18,5 \mathrm{~kg} / \mathrm{m}^{2}\right)$ hingga tingkat berat $(<17,0$ $\mathrm{kg} / \mathrm{m}^{2}$ ). Apabila seseorang termasuk dalam kategori berat badan kurang tingkat ringan atau KEK ringan perlu mendapatkan penanganan yang tepat untuk menaikkan berat badan agar mencegah terjadinya IMT menjadi $<17,0$ yaitu keadaan seseorang yang memiliki berat badan kurang tingkat berat atau KEK berat. $^{1}$

Subjek perempuan sebanyak 32 orang (69,6\%) yang mengalami status gizi kurang di pusat kota Pekanbaru (SMA Negeri 5 Kota Pekanbaru) lebih banyak didapat daripada subjek laki-laki sebanyak 14 orang (30,4\%). Hal yang sama ditemukan di pinggiran Kota Pekanbaru (SMA Negeri 3 Kota Pekanbaru), dengan jumlah subjek perempuan sebanyak 26 orang (56,5\%) dan laki-laki sebanyak 20 orang (43,5\%). Hal ini sejalan dengan dengan penelitian Dwiningsih yang menyatakan bahwa status gizi kurang lebih sering pada subjek perempuan yaitu $79,6 \%$ di wilayah perkotaan dan di wilayah pedesaan sebanyak $75,6 \%{ }^{18}$

Jumlah subjek yang mengalami status gizi kurang di pusat kota Pekanbaru (SMA Negeri 5
Pekanbaru) sebanyak 32 orang (69,6\%) lebih besar dari jumlah status gizi kurang di pinggiran kota Pekanbaru (SMA Negeri 3 Pekanbaru), sebanyak 26 orang (56,5\%). Hal ini sejalan dengan penelitian Setyawaty dan Setyowati yang mendapatkan bahwa remaja kurus lebih banyak ditemukan di wilayah perkotaan (47,9\%) dibandingkan diwilayah pedesaan $(59,2 \%){ }^{19}$

\section{Gambaran kesadaran remaja kurus tentang latihan fisik}

Berdasarkan hasil penelitian ini (Gambar 1), seluruh remaja kurus di kedua sekolah yang memilliki kesadaran tentang latihan fisik dalam kategori cukup yaitu 71 orang $(77,2 \%)$ yang masing-masing 35 orang (76,09\%) di SMA Negeri 5 Kota Pekanbaru dan 36 orang $(78,3 \%)$ di SMA Negeri 3 Pekanbaru. Kesadaran terhadap latihan fisik dimulai ketika remaja tersebut melihat bentuk tubuh sehingga remaja tersebut melakukan berbagai cara untuk mendapatkan bentuk tubuh yang ideal, salah satunya dengan melakukan latihan fisik yang dapat dilakukan di pusat kebugaran atau fitness center. Terdapat variasi program latihan yang bisa dilakukan seperti treadmill, calory burner dan latihan beban. Penelitian ini menunjukkan kesadaran semua subjek dalam kategori cukup, tetapi memiliki kondisi status gizi kurang. ${ }^{20}$

Pada penelitian ini, pernyataan favorable yang paling banyak dijawab "Ya" pada nomor 2 (Saya telah memahami bahwa latihan fisik dapat membantu saya tidak lagi mengalami status gizi kurang (berat badan kurang). yang artinya subjek paham dan sadar latihan fisik dapat membantu agar tidak terjadinya status gizi kurang. Hal ini tidak sejalan dengan penelitian Fitriah yang menyatakan bahwa kesadaran melakukan latihan fisik membantu dalam mengurangi berat badan, karena dengan latihan fisik akan meningkatkan metabolisme tubuh akibatnya cadangan energi yang tertimbun dalam tubuh berupa zat lemak dapat terbakar. ${ }^{21}$ Selain latihan fisik, asupan makanan yang adekuat sangat mempengaruhi tetapi asupan makan yang tidak adekuat dan intensitas latihan fisik yang tinggi menyebabkan ketidakseimbangan antara penggunaan dan masuknya energi dari asupan makanan tersebut sehingga dapat menimbulkan status gizi kurang. ${ }^{6,7}$ 
Selanjutnya pada penelitian ini, pernyataan unfavorable kedua terbanyak dijawab "Ya" pada nomor 8 (saya tidak yakin dengan mengatur latihan fisik tubuh saya akan kembali sehat) yang artinya subjek tidak yakin dalam mengatur latihan fisik dapat membuat tubuh kembali sehat. Hal ini tidak sesuai dengan teori pada pengertian latihan fisik yang merupakan kegiatan yang dilakukan seseorang untuk meningkatkan dan memelihara kebugaran tubuh, serta dianjurkan pada setiap individu agar terhindar dari berbagai macam penyakit. ${ }^{5}$

Berdasarkan penelitian ini, pernyataan favorable yang paling banyak dijawab "Tidak" pada nomor 7 (saya memahami perlunya latihan fisik secara teratur karena dapat meningkatkan berat badan) yang artinya keseluruhan subjek tidak mempunyai kesadaran untuk melakukan latihan fisik agar meningkatkan berat badan, akibatnya banyak subjek yang menderita status gizi kurang. Menurut penelitian Djoko, latihan harus disesuaikan dengan tujuan latihan fisik itu sendiri, jika untuk menambah berat badan dapat melakukan latihan beban dan latihan fisik harus dilakukan secara teratur agar tidak menurukan kebugaran fisik dan dapat meningkatkan berat badan. ${ }^{22}$

Hasil penelitian ini di pusat Kota Pekanbaru, pernyataan unfavorable kedua terbanyak dijawab "Tidak" nomor 1 (saya belum pernah mendengar cara melakukan latihan fisik dalam mengelola status gizi kurang (berat badan kurang)), yang artinya remaja kurus di pusat kota Pekanbaru sadar dan mengetahui cara melakukan latihan fisik yang baik dan benar. Menurut penelitian dari Suharjana, latihan fisik yang dilakukan dengan baik dan benar dapat memberikan perubahan pada sistem tubuh, baik itu sistem metabolisme, sistem saraf dan otot maupun sistem hormonal dan salah satu latihan yang dapat mencegah terjadinya status gizi kurang adalah latihan beban. $^{23}$

Berdasarkan penelitian ini, pernyataan favorable paling sedikit dijawab "Ya" adalah nomor 7 (saya memahami perlunya latihan fisik secara teratur karena dapat meningkatkan berat badan) yang artinya sedikit remaja kurus yang paham untuk melakukan latihan fisik untuk meningkatkan berat badan mereka. Menurut Wirianto adalah latihan fisik yang mempengaruhi peningkatan massa otot adalah latihan fisik yang bersifat kekuatan, contohnya olahraga latihan angkat beban. Olahraga tersebut lebih mudah untuk meningkatkan massa otot. ${ }^{7}$

Hasil penelitian ini di pingggiran Kota Pekanbaru menunjukkan pada pernyataan unfavorable paling sedikit dijawab "Ya" adalah nomor 5 (saya tidak memahami hubungan antara latihan fisik dengan status gizi kurang (berat badan kurang). Artinya remaja kurus dalam penelitian ini yang mengetahui hubungan antara latihan fisik dengan status gizi kurang. Latihan fisik membutuhkan energi namun apabila intensitas latihan fisik tinggi disertai dengan asupan makanan yang kurang daripada energi yang keluar, maka akan terjadi status gizi kurang. ${ }^{6,7}$

Penelitian ini juga menunjukkan pernyataan favorable paling sedikit dijawab "Tidak" pada nomor 2 (saya telah memahami bahwa latihan fisik dapat membantu saya tidak lagi mengalami status gizi kurang (berat badan kurang/kurus)), yang artinya adalah sedikit dari keseluruhan subjek tidak memiliki kesadaran bahwa latihan fisik dapat membantu subjek tersebut tidak lagi mengalami status gizi kurang. Latihan fisik yang dilakukan secara teratur dan kontinyu akan menyebabkan perubahan fisiologi serta dapat memperbaiki penampilan fisik sehingga subjek tidak mengalami status gizi kurang dan salah satu latihan yang dapat mencegah terjadinya status gizi kurang adalah latihan beban. ${ }^{23}$

Pada penelitian ini, paling sedikit dijawab “Tidak” pada pernyataan unfavorable nomor 8 (saya tidak yakin dengan mengatur latihan fisik tubuh saya akan kembali sehat), yang artinya subjek sedikit menjawab yakin dalam mengatur latihan fisik dapat membuat tubuh kembali sehat yang artinya masih banyak remaja kurus yang yakin untuk melakukan latihan fisik agar tubuh mereka tetap sehat. Tujuan dari latihan fisik itu sendiri adalah untuk meningkatkan kesegaran jasmani dan menjaga kesehatan. Kesadaran untuk melakukan latihan fisik yang baik dan benar dapat membuat tubuh memiliki berat badan normal apabila dipraktikkan dalam kesehariannya. Akan tetapi, karena keseluruhan subjek memiliki kondisi status gizi kurang, artinya kesadaran ini tidak dipraktikkan oleh remaja kurus tersebut. $^{5}$ 


\section{Gambaran intensi remaja kurus tentang latihan fisik}

Berdasarkan hasil penelitian (Gambar 3), didapatkan hasil seluruh remaja kurus di kedua sekolah yang memiliki intensi remaja kurus tentang latihan fisik menunjukkan dalam kategori baik yaitu sebanyak 59 orang $(64,1 \%)$ yang terdiri dari SMA Negeri 5 Kota yaitu sebanyak 33 orang $(71,7 \%)$, dan SMA Negeri 3 Kota Pekanbaru sebanyak 26 orang (56,5\%)

Pada penelitian ini, pernyataan "Sangat Ingin" yang paling banyak dijawab oleh seluruh subjek di kedua sekolah adalah pertanyaan nomor 1 (saya sebagai penderita berat badan kurang "Sangat Ingin" meluangkan waktu untuk berolahraga yang tepat/ sesuai panduan), yang artinya mayoritas subjek sangat ingin meluangkan waktu untuk berolahraga yang tepat atau sesuai dengan panduan yang ada. Hal ini sejalan dengan penelitian Andreanto pada remaja di Surabaya yang didapatkan bahwa mayoritas remaja (50\%) mempunyai masalah untuk melakukan latihan fisik yaitu masalah dalam membagi waktu. ${ }^{20}$

Pada hasil penelitian ini, menunjukkan pernyataan “Tidak Ingin” yang paling banyak dijawab oleh seluruh subjek di kedua sekolah adalah pertanyaan nomor 8 yaitu (saya sebagai penderita berat badan kurang “Tidak Ingin” untuk pengelolaan latihan fisik yang saya lakukan tidak terhambat oleh alasan ketidaktersediaan fasilitas/sarana olahraga) artinya penderita berat badan kurang tidak ingin pengelolaan latihan fisik yang dilakukan, tidak menghambat subjek dengan alasan tidak tersedianya fasilitas atau sarana yang memadai, sedangkan alatalat tersebut hanya tersedia di pusat kebugaran atau gym, dan untuk bisa menggunakan alat-alat tersebut seorang remaja harus terdaftar sebagai anggota dan dikenakan biaya. Keuangan remaja biasanya masih berasal dari orang tua dan hal tersebut menjadi kendala bagi mereka untuk mendaftarkan diri di pusat kebugaran atau gym. ${ }^{24}$

Berdasarkan hasil penelitian ini, pernyataan "Sangat Ingin" adalah paling sedikit dijawab pada pertanyaan nomor 8, yaitu (saya sebagai penderita berat badan kurang “Sangat Ingin” untuk pengelolaan latihan fisik yang saya lakukan tidak terhambat oleh alasan ketidaktersediaan fasilitas atau sarana olahraga), yang artinya sedikit yang menginginkan melakukan pengelolaan latihan fisik yang tidak terhambat karena tidak tersedianya fasilitas atau sarana olahraga yang memadai. Hal ini karena menurut Sepriyadi, beberapa remaja lebih sering melakukan jenis latihan fisik berupa lari yang tidak membutuhkan fasilitas atau sarana, sehingga hal ini lah yang menyebabkan sedikit yang menjawab sangat ingin pada pernyataan nomor $8 .^{25}$

\section{SIMPULAN}

Berdasarkan hasil penelitian terhadap 92 subjek pada SMA Negeri 5 dan 3 Pekanbaru, remaja kurus yang paling banyak ditemukan adalah perempuan dengan subjek sebanyak 58 orang (63,0\%). Usia subjek terbanyak adalah 16 tahun dengan IMT yaitu 17,80 (13,86-18,48). Remaja kurus di pusat Kota Pekanbaru dan pinggiran Kota Pekanbaru sebagian besar memiliki kesadaran tentang latihan fisik dalam kategori cukup, yaitu 71 orang (77,2\%). Sedangkan remaja kurus di pusat Kota Pekanbaru dan pinggiran Kota Pekanbaru sebagian besar memiliki intensi tentang latihan fisik dalam kategori baik, yaitu 59 orang $(64,13 \%)$.

\section{DAFTAR PUSTAKA}

1. Kementerian Kesehatan Republik Indonesia. Peraturan Menteri Kesehatan RI No 41 Tahun 2014 tentang pedoman gizi seimbang. Jakarta: Menkes RI; 2014:17-50.

2. Fryar CD, Ogden CL. Prevalence of underweight among children and adolescents aged 2-19 years: United States, 1963-1965 throught 2007-2010. 2012. Dikutip dari : https://www.cdc.gov/ nchs/data/hestat/underweight_child_11_12/ underweight child 11 12.htm. [Diakses 23 September 2018]

3. Departemen Kesehatan Republik Indonesia. Riset kesehatan dasar nasional. Jakarta: Depkes RI;2010:48-59.

4. Departemen Kesehatan Republik Indonesia. Riset kesehatan dasar nasional. Jakarta: Depkes RI;2013:219-21.

5. Simanjuntak RH, Engka JNA, Marunduh SR. Pengaruh latihan fisik terhadap saturasi oksigen pada pemain basket mahasiswa Fakultas 
Kedokteran Unsrat. Jurnal Biomedik. 2016;4(1):20-24.

6. Sundgot BJ, Torsveit MK. Aspects of disorders eating continuum in elite high-intensity sports. Scand J Med Sci Sports.2010;20(2):112-21.

7. Wirianto G. Fisiologi dan olah raga. Yogyakarta: Graha Ilmu;2013.

8. Hastjarjo D. Sekilas tentang kesadaran (Consiousness). Buletin psikologi. 2005; 13(2):81

9. Ajzen. Attitude, Personality and Behavior. Second Edition. 2005.

10.World Health Organization. Recognizing adolescene. 2014. Dikutip dari: http:// apps.who.int/adolescent/second-decade/ section2/page1/recognizing-adolescence.-html [Diakses 23 September 2018].

11. Stang J, story M. Adolescent growth and development. Guidelines for adolescent nutrition services. adolescene.book.shtm.2005:1-7.

12. Firi RP. Pengaruh teman sebaya, pengetahuan, media massa terhadap perilaku diet mahasiswi Stikes Payung Negeri Pekanbaru. Jurnal Endurance. 2018;3(1):162-8.

13.Sebataraja LR, Oenzil F, Asterina. Hubungan status gizi dengan status sosial ekonomi keluarga murid sekolah dasar di daerah pusat dan pinggiran kota Padang. 2014;3(2):182-83.

14.Zahtamal, Restuastuti T, Restilla R. Pengaruh intervensi latihan beban pyramid set dan konsumsi makanan tinggi protein terhadap IMT dan massa otot remaja underweight. Universitas Riau;2018.

15. Natanael Y, Sufren. Belajar otodidak SPSS pasti bisa. Jakarta: Gramedia;2014: 56.

16. Deren K, Nyankovskyy S, Nyankovskyy O, Tuszcki E, Wyszynska J, Sobolewski M, et al. The prevalence of underweight, overweight and obesity in children and adolescent from Ukraine. Scientific Reports.2018;8(1):2-3.
17. Damayanti AE, Hubungan citra tubuh, aktivitas fisik, dan pengetahuan gizi seimbang dengan status gizi remaja putri. [Skripsi]. Surabaya: Fakultas Kesehatan Masyarakat Universitas Airlangga Surabaya; 2016.

18. Dwiningsih, Pramono A. Perbedaan asupan energi, protein, lemak, karbohidrat dan status gizi pada remaja yang tinggal di wilayah perkotaan dan perdesaan. Journal of Nutrition College. 2013;2(2):234-8.

19. Setyawati VA, Setyowati M. Karakteristik gizi remaja putri urban dan rural di Provinsi Jawa Tengah. Jurnal Kesehatan Masyarakat. 2015;11(1):46-50.

20. Andreanto A. Aplikasi perilaku terencana: Niat melakukan physical exercise (latihan fisik) pada remaja di Surabaya. [Skripsi].Surabaya: Fakultas Psikologi Universitas Surabaya.2013.

21.Fitriah JN. Hubungan asupan zat gizi, aktivitas fisik, dengan status gizi pada peserta senam aerobik. [Skripsi]. Semarang: Fakultas Kedokteran Universitas Diponegoro. 2007.

22.Djoko P. Pedoman Praktis Berolahraga untuk Kebugaran dan Kesehatan. Yogyakarta: C.V Andi Offset;2006.

23. Suharjana. Latihan beban: sebuah metode latihan kekuatan. Jurnal Medikora.2007;3(1):80-101.

24.Dambros DD, Luis FDL, Daniela LDS. Perceived barriers and physical activity in adolescent students from a Southern Brazillian City. Rev Bras Cineantroponom Desempho Hum.2011;13(6):422-28.

25. Sepriadi, Sefri H, Hilmainur S. Perbedaan tingkat kesegaran jasmani berdasarkan status gizi. Jurnal Media Ilmu Keolahragaan.2017;7(1):25-33 